\title{
広域的強化学習によるデジタル情報推薦の活性化手法
}

\author{
非会員 田 野 俊 一 (電通大) \\ 非会員 木 根 智 也 (日本ビクター(株)) \\ 非会員 石 谷 規 彦（(株)ウェザーニューズ）
}

\section{Digital Information Recommendation System Activated by Reinforcement Learning in Society}

\author{
Shun'ichi Tano, Non-member (University of Electro-Communications), Tomoya Kinone, Non-member (VICTOR \\ Company of Japan, Ltd.), Norihiko Ishitani, Non-member (Weathernews Inc.)
}

\begin{abstract}
The Internet, multimedia applications and digital devices have been ubiquitous in our society. Most people have their own PCs and can easily access to the World Wide Web site or on-line news. A system that can learn what information or programs a viewer wants or enjoys and that can then recommend them to the viewer would be a solution to the situations. In this paper, problems with conventional approaches are made clear by analyzing conventional methods of recommendation. Introducing reinforcement learning in society enables the system to recommend two kinds of serious programs. An evaluation of the new method is presented.
\end{abstract}

キーワード: 情報推薦, コンテンツベース推薦, コラボレーティブ推蔗, 強化学習, ソーシャルフィルタリング

\section{1 はじめに}

デジタル化・マルチメディア化・ネットワーク化と言わ れるようになって久しい，家庭にはパソコンが普及しイン ターネットを利用すれば誰でも無数のウェブサイトを見る ことができ, ニュース配信サービスを利用すれば，最新の ニュースを手に入れられるようになった．また，放送のデ ジタル化によってC S 放送ではチャンネル数が 300 を越 え,多種多様な番組が放送されている.

しかし，この膨大な情報は新たな問題を生じる．即ち， 人間の情報搷取行動には限界があり。これだけ膨大な情報 は処理しきれない．例えば，ユーザが一日に見るテレビ視 聴時間は約 3 時間(1)で一定している．3時間という限られた 視聴時間のなかでユーザが自分の見たい番組を数百チャン ネルの中から選ぶのは非常に因難である.ある調査 ${ }^{(2)}$ では T $\mathrm{V}$ 視聴者の約半数が「あらかじめ希望した番組を自動的に 次々と見る事ができる」サービスを期待している.

このような環境下では，ユーザが望む情報を簡単に入手 できるように、ユーザの特徵を学習しユーザの情報搷取活 動を支援する情報推萀システムが必要になると考え, 研究 を進めている(3)〜(6).

本墖文では, 従来の情報推萀技法の問題点を分析し, 新 しい情報推萀技法を提案し, その効果を分析する． 2 章で は情報推萀技法に関する従来技術を概観し，3 章ではその 問題点をまとめる. 特にコラボレーティブホライズン問題
を指摘する４４章では，情報推蔍に関し新たな手法の提案 を行い，5章ではシミュレーションによる評価を行う。最 後にまとめと今後の展開について述べる.

\section{2. 従来手法}

本章では，従来の情報推蔍技法および推焤システムにつ いてまとめる.

$\langle 2 \cdot 1\rangle$ 従来の推薦技法従来の推蔍技法は大きく分 けて2つに分類される，コンテント(内容)ベース推腐とコラ ボレーティブ(協調的)ベース推荿である(7)(8).

(1) コンテントベース推薦

エージェントがユーザの情報摄取行動を肩越しに眺め ユーザの情報提取履歷を取得し，その履歴を基にユーザの 選好在表現する”プロフィール”を学習する，プロフィール とは、「ドラマが好き，SFが嫌い」などの固人ごとの好き 嫌いに関する情報である．このプロフィール基づき推萀す る方法がコンテントベース推蔗である.コンテントベース 推䳡の原型は文書検索システムにあり，ユーザの指定する キーワードに対してシステムはそれに関連する重要なキ一 ワードを含む文書を推熫する方法である。

コンテントベース推萀では，コーザが行った行動の情報 掑取履歷を基に情報推薦されるので, ユーザの要望どおり 
の情報推薦が行われやすく，また，推薦した情報の評価が エージェントにフィードバックされプロフィールが更新さ れユーザの好みに適応していくという利点を持つ.

(2) コラボレーティブ推萀

コラボレーティブベース情報推薦では，あるユーザと似 たプロフィールを持った他人のプロフィールを利用して情 報の推菣を行う．つまり自分と似た他人のプロフィールを 元にコンテンツ推葴を行うという技法である。

ユーザは興味を持つ可能性がある新しい情報の推腐を受 ける事ができるという利点を持つ。

〈2・2〉従来の推薦システム WWW上での研究事例 としてWebWatcher(9), 奏際に稼動しているシステムとし てはAlexa(10)があげられる.

WebWatcherはユーザのブラウンジング履歴を利用し， 興味のあるキーワードを学習していき，WWW上でのキー ワードによる重複頻度を調ベ，ある条件(頻出頻度)を超え たものがWWWページ上で強調される．この推薦システム は大まかに分類するとコンテントベース推薦にあてはま る.

Alexaの推鷹方法として手がかりになっているのはユーザ の推薦とブラウジングの履歴である. 推蔄方法としては不 特定多数のユーザからの大量の推薦や情報摂取履歷情報を 基にWWWページの有用性や関連性を求め, それをユーザ 八の推萀として用いている.この背景には，「WWWにおけ るリンクはWWWページの設計者が自由に設定することが できる」それらは蜘蛛の巣状に張り巡らされているため ユーザは自分の見たいページを見つけづらい」しかしその リンクをたどるユーザのパターンにはある程度の規則性が 存在するはずである」有用なりンクに対しては多くのユー ザがたどるであろうし，そうでないリンクはほとんど誰も たどらないであろう」という考えが原点にある．この推薦シ ステムはコラボレーティブベース推薦に近い性質を持つ.

コンテントベースやコラボレーティブベースでの推薦は それぞれ利点と欠点を持つ．それら推蔍技法の欠点を補う システムとして両方の推蔗技法を融合した推萀システムが 最近では主流になりつつあり研究されている。例えば Fabsystem ${ }^{(8)}$ である.

Fabsystemはエージェントを利用した情報推萀システム である. システムとしてはコレクションエージェントとセ レクションエージェントを利用して情報推葴を行う。推蔍 方法としては，セレクションエージェントがコラボレー ティブ推薦行動をする. そしてコレクションエージェント はコンテントベース推腐を行う。これら二つのエージェン トが相互作用することによりコンテントベースの欠点であ るユーザが好むかもしれない情報の推薦が行われる. 又コ ンテントベースの利点である推萀の成功率の向上も見込ま れる. 二つの推萀技法を融合させることによって，効果的 な情報推薦結果が得られている。

\section{3. 従来手法の問題点}

従来の情報推蔍手法の本質的問題点は，下記に説明する 2 点に分類することができる.

\section{〈3・1〉問題点 1 : 人間の自発的情報摄取行動への依存}

コンテントベース推貒技法はユーザの履歴を重視するた め、ユーザが過去に見たこともないような番組の推蔍はで きない。この点を克服する手段として，他人のプロ フィールを利用するコラボレーティブベース推薦が生まれ た。しかしながら，不特定多数のユーザの情報椇取履歴を 利用するため，その情報源である情報搷取履歴情報が少な い場合，有効な推薦ではできない。コラボレーティブ推萀 は自分に似た人の情報椇取㕍歷に依存しているからであ る. 例えば，自分と情報提取履歴が似た人が活発にさまざ まな新しい番組を見て，よい番組を探し出してくれる場 合, コラボレーティブ推萀の効果は高い. しかしそのよう な人がいない場合，コラボレーティブ推薦される番組は限 定されてしまうのである.

即ち、第一の問題点は従来の推䉆システムでは人間の自 発的な情報摄取行動に重きを置きすぎている点である．確 かに人間の情報摄取行動から得られる情報攝取履歴なしに は情報の推薦をすることができない.しかしながら人間の 情報摂取行動には限界がある，しかもこれからの情報環境 では数限りない情報が発信される．このような人の存在を 前提にする従来の推闖技法は本質的な問題点を抱えている と言わざるを得ない。

〈3·2〉 問題点 2 : コラボレーティブホライズン コラ ボレーティブ推薦では自分とプロフィールが似ている他人 のプロフィールの利用に利点がある、自分は自分に似てい るBの，BはBに似ているCの情報を利用する。このように 自分から $\mathrm{B} ， \mathrm{~B}$ から $\mathrm{C}$ のうに情報推鷹の仮想的なネット ワークができる．このネットワークが閉じたグループを構 成してしまうとこのグループに入っていない他の人からこ のグループヘのコラボレーティブ推蔿が行われない.コラ ボレーティブ推萀のネットワークの地平線があるという意 味で本研究では「コラボレーティブホライズン問題」と呼ん でいる. 閉じた仮想的なグループをホライズングループと 呼ぶ。

例えば図 1 に示すように，あるユーザ同士の選好が似て いて，ユーザ同士でグループA，グループBを作ったとしよ う.グループAのユーザXがある番組 $\alpha$ を見たとする．そう するとこのユーザXのプロフィール情報により，番組 $\alpha$ はク ループAの中ではコラボレーティブ推薦により推薦されてい く.しかしこの番組 $\alpha$ はグループBには広がることはない. なぜなら番組が推薦されていくネットワークが途中で切す ているからである. グループBにとってもこの番組 $\alpha$ は有斥

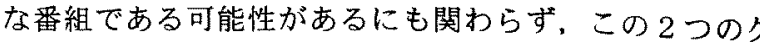


ループ間にはコラボレーティブホライズンがあるため, ネットワークが交わらず,この番組は推葴されていかな い.

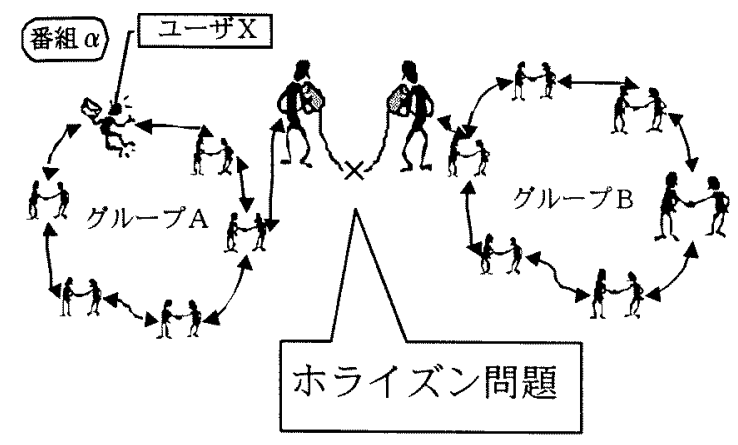

図 1 コラボレーティブホライズン問題

Fig.1 Collaborative Horizon Problem

\section{4. 広域的強化学習による情報推萀}

広域的強化学習推薦では従来の推蔍手法における上記 2 つの問題点の解決を目的としている．以下に，解決のため のアプローチ, 基本となる 3 つコンセプト. エージェン トアーキテクチャによる実現について説明する.

〈4・1〉 アプローチ＼cjkstart第一の問題点は従来の推薦技法 がユーザの自発的な情報掑取行動に頼るところにある。そ のため従来の推薦では未知番組は推薦されない。ここでの 末知番組とは，ユーザが與味を持つかもしれない，新しい ジャンルの番組を指す，正確には，(1) ユーザの誰にも見ら れていない種類の番組, あるいは，(2)ホライズングループ 中のユーザの誰にも見られていない種類の番組である。こ れらの番組が推茂されるか否かは，ユーザの情報椇取行動 に深く依存している．つまり，自発的に情報摂取行動を行 うユーザが少ない場合、これらの番組は推葴されることは ない.このようにユーザの情報摂取行動に大きく依存して いる点が従来の推萀技法の根本的な弱さである．ユーザの 情報摂取行動に影響されない推薦が重要になる。

第二の問題点である「コラボレーティブホライズン」は, 推萀システム(エージェント)がユーザと同じ位置に存在す る限り見えない，しかしユーザが存在する立場からひとつ 上の立場で情報伝達の流れを分析するとホライズンが見え てくる. 全体的な情報伝達の流れの分析が重要になる.

〈4・2〉基本コンセプト提案する広域的強化学習推 薦は以下の3つのコンセプトに基づき設計されている.

\section{(1) ユーザに対しての「試し」推蔍}

広域的強化学習推萀の基本コンセプトはユーザに対して 「試し」に推薦してみることである。「試し」の推萀とは， ユーザに一種のうそをつく行動であり，通常の場合，悪い 行動であるが,これにより情報の推腐が活性化されるので
ある.

つまり，末知番組は従来の推萀方法では推萀されること がないが，ユーザにとって有用な番組であるかもしれな い.このような番組はTVのディジタル化による情報の大量 化に伴い，数多く出現すると考えられる．そこである基準 で選んだユーザに対して、未知番組を面白い番組として推 薦する。個々のユーザにとってこの未知番組の推薦は迷惑 な推萀かもしれない，しかし社会的にはこれらの一部の ユーザに視聴させることにより，未知番組がコラボレー ティブ推薦などを介して有用な番組として社会全体に推鷹 されていく.

(2) コラボレーティブホライズン

従来の推蔍システムではホライズン問題が起き，推蔍に よる有用な情報の伝達が限定される可能性がある，ホライ ズングループを認識し，各ホライズングループにとっての 未知番組を検知し，各ホライズングループ内で上記(1)を実 行する.つまり，各ホライズングループにとつての未知番 組を，ある基準で選んだそのホライズングループ内のユー ザに対して，未知番組を面白い番組として推薦する。これ により,コラボレーティブホライズンによって遮られた情 報の伝播が再び活性化される。

（3）社会の性質とユーザの性質への適応

上記(1)(2)で説明した「試し」推萀は一種のうそをつくこと であり，その対象，頻度等の基準を適切に設定することが 重要である.

この基準設定には複数の要因が関倸すると考えられる. 例えば，番組の制作される社会の性質である，末知番組が 活発に制作される社会では上記(1)と(2)の効果は大いに期待 できる.しかしそうではない社会においては逆効果の場合 もありうる。

また，番組を視聴するユーザの性格も考慮する必要があ る. 新規で新しいジャンルの番組を推萀されることを喜ば しいと思うユーザ(あたらし物好きのユーザ)にとっては上 記(1)と(2)による推䳸は効果的に働く可能性がある。しか し，反対にユーザにとって面白くない番組の推薦を非常に 嫌うユーザ(自分の好きなものだけ視聴したいユーザ)に とっては上記(1)と(2)による推薦は効果的に働かない可能性 がある。

以上示したように, 上記(1)と(2)による推薦は, 社会の性 質やユーザの性質を認識し，その社会にあった推萀方法や ユーザ選定基準を決めることが非常に重要である.

そのような性質は事前に把握することは困難であり，か つ, 時間とともに変化していくと考えられる. システムが 社会の変化を認識し，その社会に適した推䳸手法を適応的 に学習する機能が必須となる.

そこで, この適応的学習機構を, 未知環境でのエージエ ントによる自律的な学習モデルである強化学習 (QLearning)(11)を用いて設計した。この学習機構は，現在の 
社会とユーザの性質に適した推䳡手法を次第に学習する。

即ち，推薦手法として，

・コンテントベース推萀

・コンテントベース+コラボレーティブ推薦,

・コンテントベース+コラボレーティブ+「試し」推薦 のいずれが適しているか，また，

・「試し」に推薦する割合 $\alpha$ (これを広域度 $\alpha$ と呼ぶ) の適切な值をQ-learningにより試行錯誤を繰り返しながら 学習していく。

上記の(1)(2)(3)を満たす情報推萀技法を, 「広域的な社会 全体で適切な情報推腐技法を強化学贸で実現する」という意 味で「広域的強化学習推鹰」と呼んでいる. 図 2 に広域的強

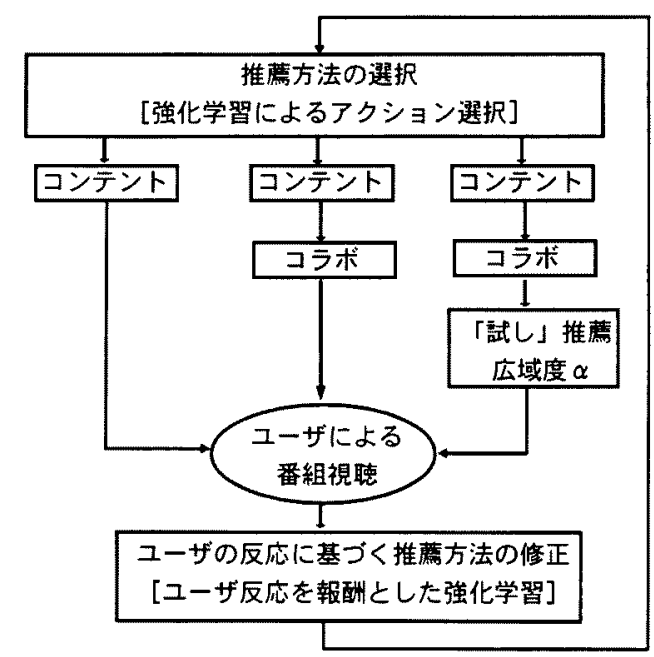

化学習推薦の全体フローを示す

図 2 広域的強化学習推薦の全体フロー

Fig.2 Flow of Information Recommendation by Reinforcement Learning in Society

〈4·3〉 エージェントアーキテクチャ 広域的強化学 習は，二種類のエージェント，即ち，ユーザエージェント と広域的強化学習エージェントから構成されるエージェン トアーキテクチャで実現されている。これら 2 種類の工一 ジエントはそれぞれ独立して行動する。ただし広域的強化 学習エージェントはユーザエージェントより上位のエー ジェントである. 図 3 にエージェントアーキテクチャの全 体像をまとめる，図 2 および図 3 を用いて，各エージェン トの動作，全体の動作を説明する.

（1）ユーザエージェントの動作

ユーザエージェントはユーザごとに存在する、ユーザ エージェントは大きく分けて 2 つの機能を持つ. 広域的強 化学習エージェントの指示に基づき情報を推噳する機能(図 3 のU1，U2, U3), および, 担当するユーザの行動を肩越 しに眺め，番組視聴に対するユーザのプロフィールを作 成・更新する機能(U4)である，情報を推薦する機能には，
プロフィールを基に番組を推焤するコンテントベース推蔗 機能(U1)，他人のプロフィールを利用して番組を推薦する コラボレーティブ推鹰機能(U2)，および，「試し」に推薦す る機能(U3)から構成されている.

ユーザエージェントは，ユーザのプロフィールの推定值 を持っている.これを用いて，特定の番組がユーザによっ て面白いかどうかを判定したり(U1)，自分と似ている他人 を探す(U2)，また，ユーザの番組に対する「面白い」面白く ない」という反応をを元に，ユーザプロフィールの推定值を 更新する(U4). 例えば, プロフィールに存在しない新しい 種類の番組を見てくとても面白い」という反応をした場合, この番組が「好ましい情報として，プロフィールに新たに 追加される。

（2）広域的強化学習エージェントの動作

広域的強化学習エージエントは，放送される(制作され る)番組を検出し(図 3のL1)，この番組に対して，全ユ一ザ のプロフィールを参照して，どのくらいのユーザに好まれ そうか/嫌われそうか，あるいは，未知の番組であるかを 分析する(L2).

次に, 図 2 に示すように, 分析結果を元に各ユーザエー ジェントに対して，実行すべき推萀方法として，コンテン ツベース推腐ノコラボレーティブ推腐ノ「試し」推薦(広域度 a) を指示する(図 3 のL3)，特に，その番組がユーザ全員あ るいは，特定のホライズングループにとって未知番組であ ることが判明した場合は, ある基準 (広域度 $\alpha$ と呼ぶ)で選 んだユーザに，有用な番組であるとして「試し」に推鬳する ことをユーザエージェントに指示する.

以上により，害際の推薦が行われ，ユーザは推薦に対し 即座に拒絶することや，面白く視聴するなどの反応を起こ すこのユーザの推萀結果に対する反応を元に，ユーザ エージェントは自分の担当するユーザのプロファイルの修 正を行うとともに(U4), 広域的強化学習エージェントはL3 で用いた推薦法や広域度 $\alpha$ の選択基準を強化学習を用いて 修正する(L4).

(3) 全体の動作

総合的な処理の流れは以下のようになる.

Step 1：ある番組の制作を検出(L1)

Step 2:その番組の特性を分析(L2)

Step 3 : 適切な推鹰技法 (必要なら広域度 $\alpha$ も) 算出 し，ユーザエージェントに指示(L3)

Step 4: 指示に従い，番組推蘑を実施(U1,U2,U3)

「試し推䳸」の場合は, 確率 $\alpha$ でランダムに推鷹

Step 5: ユーザの反応により, 個々のプロフィール を訂正(U4)

Step 6: 全ユーザの反応を元に, 推萀法や広域度 $\alpha$ の選択基準を強化学羽により修正(L4) 


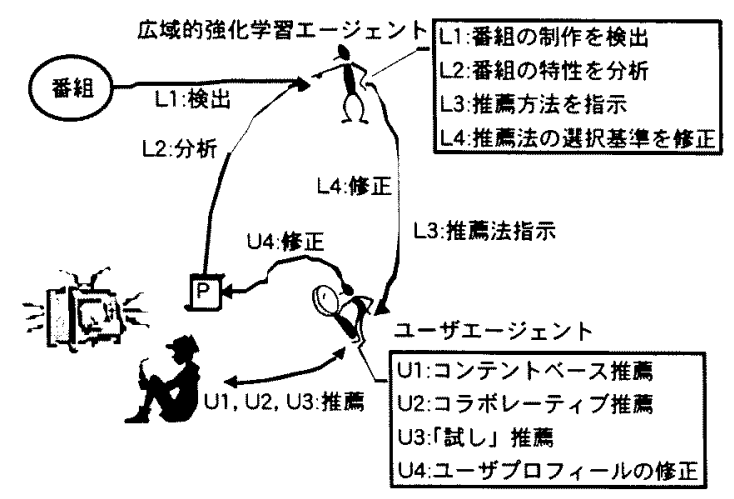

図 3 エージェントアーキテクチャ

Fig3 Agent Architecture

\section{5.シミュレーションによる評価実験}

広域的強化学習システムを実装し、シミュレーションに よる評価実験を行った。まず広域的強化学習システムの実 装方法を述べ，次にシミュレーション評価方法，シミュ レーションフロー, 最後に 3 つの評価実験の結果を説明す る.

\section{〈5・1〉広域的強化学習システムの実装方法}

前節 4.3で説明した機能L1-4，U1-4の実装方法を述べる.まず 共通データ構造である, 番組・プロフィールの表現方法, 強化学習のためのQ-tableの形式を説明し, 次に, 各エー ジェントの実装について示す.

(1) 番組・プロフィールの表現方法

番組の種類はワードベクトルなどのベクトル形式で表現 する. 今回の実験では実データではなく仮想的な 5 次元の 数值ベクトルを用いて番組の種別を表す ベクトルの值域 は $\{1,2, \ldots, 10\}$ とし， <1, 10,5,2,7>がベクトルの例であ る．例えば，第 1 要素が「ドラマ性」，第 2 要素が「S F 性」 などのような意味を持ち，值が 1 であることは，その要素 が弱いことを，10であることが強いことを表している.

これにより、全ての番組の内容はこの 5 次元のベクトルで 表現される。

一方、ユーザの選好を表すプロフィールは，この5次元 のデータに選好（好きノ嫌い）を表すデータ(\{-5，一 $4, \ldots,+4,+5\})$ を付加した計 6 次元のデータで表す．例え ば，「上記の番組がとても好き」というプロフィールは，<1， 10,5,2,7, +5>として表現される.

ユーザのプロフィールは，過去に見た番組に対するこの 6次元ベクトルのすべての集合で表すことが可能ではある が、すべてを記憶することは現獉的ではない．ここでは， ひとりのユーザのプロフィールは後述するクラスタリング 手法により最大 8 本の上記 6 次元のベクトルにまとめてい る.

（2）強化学習のためのQ-tableの形式
Q-tableは, 環境の属性, 実行すべきアクション, Q值の 3 項目から構成される。環境の属性は,

・現番組が好きなユーザ数

・現番組が嫌いなユーザ数

・現番組が好きでも嫌いでもないユーザ数

・現番組の総合的な評価値 (平均值)

・前番組の推蔍行動

・推薦すべきと判断したユーザ数／全ユーザ数

・ホライズングループ数/全ユーザ数

などを用いる，属性の值は量子化するため各属性の值は， 大, 中. 小などの 3 種類から 5 種類にラベル付けされた值 としている.

実行すべきアクションとしては，

・コンテントベース推薦のみ

・コンテント+コラボレーティブ推薦のみ

・コンテント+コラボレーティブ+「試し、推鹰(広域度A

・コンテント+コラボレーティブ+「試し」推薦(広域度B)

・コンテント+コラボレーティブ+「試し」推萀(広域度C)

の計 5 種類持つ.

広域度 $A, B, C$ 事前に定めた定値であり，例えば，1 $\%, 2 \%, 3 \%$ ある. 広域度を連続値として算出する場 合は，Q值による加重平均で計算する。

Q值は，アクションを寒行した場合に将来にわたって得ら れる報酬である．本システムの場合は，将来にわたって得 られるユーザの満足度の和, つまり，将来に渡って得られ る満足度である，満足度は，各推薦に対するユーザの主観 的な評価であり，ユーザごとに評価方法が異なると考えら れる. 本研究では, 次節で示す評価式Hで満足度を得てい る.このQ值が大きいほど好ましいアクション, 即ち実行 すべき推薦方法であることになる．

次に、シミュレーションにおける各エージエントの機能 L1-4, U1-4の実装について説明する.

（3）広域的強化学習エージェントの実装

L1: 番組の検出はシミュレータより通知される.

L2:Q-tableにおける環境の属性を計算する.

L3:Q-tableをサーチし現在の環境に合致するアクション とそのQ 值を取得し，標淮的なQ学習方法に則り， ルーレット選択で実行すべきアクションを選択する. 即ち, Q-tableより, 現時点で実行可能な複数のアク ションとそれらに対するQ值を算出し，Q值の大きい アクションが選択され易いルーレットを作成し，それ を用いて確率的に実行するアクションを選択する。こ の選択されたアクションに基づき，各ユーザエージェ ントに推蔍実行を指示する。

L4:各エージェントから各ユーザの満足度に関する情報 を取得し，その平均をとり社会全体の満足度とし、こ の满足度を元に標準的なQ值更新式を用いて修正量を 算出し、Q-tableを更新する(初期のQ-tableはランダ 
ムに設定する)。

(4) ユーザエージエントの実装

$\mathrm{U} 1$ : 番組の 5 次元ベクトル(シミュレータより与えられ る) とユーザのプロフィールにある 8 本の 6 次元ベク トルと比較し，番組に対するユーザの選好を計算す る. 好ましいと判断された番組を推萀する.

U2:他人のプロフィールと自分のプロフィールの差分を 算出し，一定以下であれば，似ていると判断し，その 似ている他人のプロフィールを用いて，上記U1を実 行する。

U3:広域度 $\alpha$ の確率でランダムに推薦する.

U4:ユーザからの推薦番組に対する選好結果 $(-5$ から+5) を受け取り，8本のプロフィールベクトルを更新す る.

具体的には，8本のプロフィールベクトルと，過去 の一定数の番組の評価ベクトル(6 次元のベクトル) を、クラスタリング手法であるK-means法にかけ， 新たな 8 本のプロフィールベクトルを算出する. 8本 のプロフィールベクトルは次第に変化していく.

〈5·2〉 シミュレーション評価方法シミュレー ションを行うためには，(1) どのように番組を生成するか, (2)推薦された番組に対するユーザの評価をどのように得る か，（3）システムの有効性を示すデータをどのように収集す るか，が問題になる.

\section{(1) 番組の生成方法}

番組の制作には一定の流行があること，あるいは，社会 によっては活発に新たな種類の番組が作成されるなど，番 組の出現には，社会的な性質が反映されると考えられる. そこで，そのような社会の性質として，新たな番組が制作 されやすさをパラメータ(「未知レベルを㭔ぶ)として，番組 を生成している. 未知レベルは 1 から 8 のレベルであり， 数字の大きい程, 未知の番組が製作されにくい社会を表し ている. 具体的には，5次元のベクトルの各要素の值をラ ンダムに 1 から 100 值をとり番組を発生させるが，過去 の一定数の番組の平均值からの規定距離にあるものを選択 することにより，未知レベルを制御している.

（2）ユーザの番組に対する評価

推薦システムが保持しているユーザプロフィールは推定 值であり，ユーザの推萹番組に対する評価は，実際にユー ザに番組を提示しその反応を分析することによってしか得 られない，奉際のケーブル T Vや衛星 T Vに組み込むこと ができれば、この奏際のユーザの反応を得ることができる が現時点では不可能である.そこで，本シミュレーション では，ユーザの真の選好を表すプロフィールを持つことに より，ユーザの番組に対する評価を計算により算出する. この真の選好は，シミュレート開始時点に乱数を用いて生
成する.このプロフィールは推薦した番組に対するユーザ の評価を得るためだけに用いられ，推薦システム自体は存 在を知らない。

(3) 収集データ

本シミュレータでは，基礎デーととて

(a) コンテントベース推荿

(b) 広域的強化学習が影響したコンテントベース推蔍

(c) コラボレーティブベース推葴

（d）広域的強化学習が影響したコラボレーティブベース 推薦

(e) 広域的強化学習によるユーザに対する直接的な推鹰 の5種の推薦に対する, 成功数, 失敗数, 無回答数(好きで も嫌いでもない番組の数)を計数する.上記の「広域的強化 学習が影響した」とは, 過去の「試し」推萀により生成された プロフィールが起因した推薦の数である.

上記(a)-(e)は基礎データであり，これを社会や個人の特 質を加味し総合的に評価するために下式の評価值Hを用い ている.

$$
H=\frac{(A+(\alpha \times B)+(\beta \times C)+(\gamma \times D))}{S}
$$

$$
\begin{aligned}
& \mathrm{S}=\text { 全推薦数 } \\
& \mathrm{A}=\text { 従来の推鷹による推䳸成功数 } \\
& \text { (上記項目, } a+c \text { ) } \\
& B=\text { 広域的強化学習による推薦成功数 } \\
& \text { (上記項目, } b+d+e \text { ) } \\
& \mathrm{C}=\text { 推蘑失敗数 } \\
& \mathrm{D}=\text { 推鹰に対するユーザの無回答数 }
\end{aligned}
$$

評価関数での $\alpha, \beta, \gamma$ は社会を構成する平均的なユー ザの性格を表すパラメータである，例えば，新しい番組の 視聴を歓迎するユーザでは $\alpha$ 数值を上げる．また番組の 推薦失敗を良しとしないユーザでは $\beta$ 数值を負の值にす る. $\alpha, \beta, \gamma$ は, $\alpha \geqq 0,0 \geqq \beta, 0 \geqq \gamma \geqq \beta$ であり, 評価関数の值域は $\alpha \geqq \mathrm{H} \geqq \beta$ 亡なる.

このパラメータ $\alpha, \beta, \gamma$ を知ることは事実上不可能で あるが, 広域的強化学習方法自体としては, このパラメー 夕は不要であり, 問題とはならない，つまり，番組推薦に 対する満足度が得らればよく， $\alpha ， \beta ， \gamma$ は不要である. 実際，推萀システムは $\alpha, \beta, \gamma$ 存在を知らない。これ は，推菣システムが、ユーザの真のプロフィールを知らな いことと同じである.

推薦システムは，ユーザプロフィールを推定するのと同 様に， $\alpha ， \beta ， \gamma$ に対応するような社会の性質に対応し て, 自動的に推薦方法を学習する. 極端な場合, 誤推薦を 極端にきらうユーザが多い社会であれば，次第に，コンテ ントベース推薦に関するQ值が大きくなり，コラボレーティ プ推薦や「試し」推薦が行われにくくなるように学習され 
る.

〈5·3〉 シミュレーションフロー～シミュレータの 全体の動作を図 4 にまとめる．まず，個々のユーザに真の プロフィールを準備し，乱数を用いて番組を制作し，図 2，3に示す推薦システムに伝える．推萀システムは, ユーザのプロフィールの推萀值やQ-tableを用いてどのよう に推薦するかを決め，番組推萀を行う，推薦番組は真のプ ロフィールと比較され，その結果がユーザの反応として， 推薦システムに返され，プロフィールの更新に使われ，ま た、下記の総合評価Hを報酬としてQ-tableの更新が行われ る.

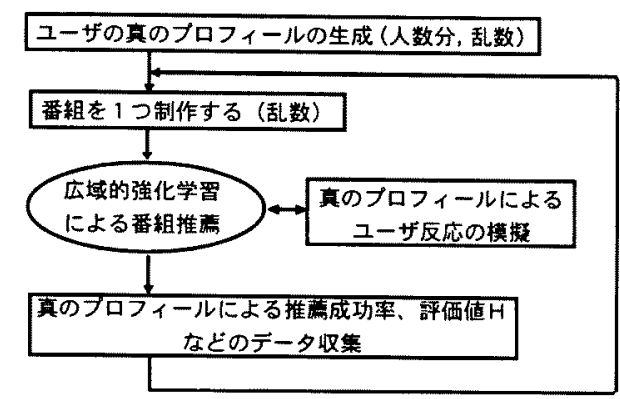

図 4 シミュレーションフロー

Fig. 4 Simulation Flow

〈5.4〉評価実験結果広域的強化学習システムに対 して以下の3点に着目して評価実験を行った。

（1）「試し」推薦の効果の検証

まず，「試し」推萀により，推萀成功率と推薦成功数がど のように変化するかを検証する実験を行った。

従来の推葴方法と広域的強化学習システムを比較するた め,

(a) コンテントベース推䳸システム

(b) コンテントベース+コラボレーティブベース推萀シス テム

(c) コンテントベース+コラボレーティブベース＋

「試し」推茂[広域度＝3\%]

の3種の推薦システムを用いて番組推薦シミュレーション を行った。

実験条件はユーザ数 100 ，生成番組数 1000 (図40 ループ回数), 未知レベル 7 である. 未知レベル 7 は末知番 組ができにくい，つまり，広域的強化学習推薦には不利な 社会の性質である．実験結果を表 1 にまとめる.

表 1 「試し」推萀の効果の検証結果

\begin{tabular}{|c|c|c|c|}
\hline & 脽薦成功数 & 推薦総数 & 成功率 \\
\hline (a) システム & 5126 & 7115 & 0.72 \\
\hline (b) システム & 5966 & 9636 & 0.62 \\
\hline (c) システム & 7234 & 12020 & 60 \\
\hline
\end{tabular}

本実験の背景には，「試し」推腐は一種の盲目的な推薦で あり，推薦成功率が大きく低下するのではないかという， 不安がある。

表 1 の結果より未知番組ができにくい未知レベル 7 であ るにもかかわらず, 推鹰の成功率を比べて見ると「試し」推 萀を用いた推薦システムは, 現在主流の「コンテント+コラ ボレーティブ推萀」とほぼ同じ成功率であり，「試し」推鷹の 方がわずかに成功率が落ちている程度に留まっている.

さらに、「試し」推萀を用いた推鷹システムは従来の $2 つ$ の推薦技法より，推腐成功数の大幅な増加（(a)に比べて $+41 \%$ ，(b)に比べて+22\%)を示している．これは広域的強化 学習システムが未知番組を検知し広域的強化学習による推 薦が行われた結果によるものである。

以上のように，広域度を適切に設定すれば，推薦成功率 を, 現在主流の「コンテントナコラボレーティブ推薦」と少 なくとも同程度に保つことができ, かつ，推薦成功数を大 きくすることが可能であることが奏証された。

この実験では広域的強化学習の広域度を $3 \%$ に固定して いる.しかし最適な広域度は社会やユーザの性質によって 変化する可能性があり、次の実験で検証する.

\section{（2）広域度の変化の影響の評価}

社会や個人の性質が，最適な広域度にどのように影響を 与えるかを調べるため, 末知レベル，広域度を変化させた 場合の評価值Hをシミュレーションにより収集した。ここ では，社会や個人の性質を加味した評価を行うために先の 章で述べた評価値 $\mathrm{H}$ 用いている.

赛験方法としては.

・未知レベルを 1 から 8 まで変化させる

・広域度を0\%〜80\%まで変化させる

・評価式は下記のように変化させる

$$
\begin{array}{ll}
\alpha=1, & \beta=0, \quad \gamma=0 \\
\alpha=2, & \beta=0, \quad \gamma=0 \\
\alpha=1, & \beta=-1, \quad \gamma=0
\end{array}
$$

のすべての組み合わせの状況において，ユーザ数 100 , 生成番組数 300 の条件で推萀シミュレーションを行い, 評価值 $\mathrm{H}$ を算出する。

実験結果の一部を図 5 ，図 6 にまとめる、横軸は広域 度, 縦軸は評価値Hである. 例えば図 5 では, 未知レベル $=8$ (新規の番組の制作が不活発)， $\alpha=1 ， \beta=-1, \gamma$ $=0$ (嫌いな番組を推鹰されることを嫌う)の社会・個人の 性質での，広域度とその時の評価値Hをプロットしてあ る.この社会・個人の性質では, 広域度は1\%程度が最適 であり，これ以外の場合は，評価值Hが極端に低下するこ とを示している，図6では異なる状況設定において，広域 度が数\%の部分を払大して表示した。

以上のように，番組推薦において，社会の性質、ユーザ 
の性質によって，最適な広域度が変化し，評価値に大きな 影響を与えることが判明した。

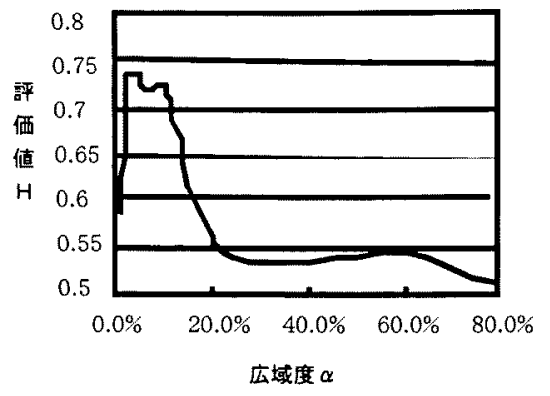

図 5 結果 1 : 未知レベル $8, \alpha=1, \beta=-1, \gamma=0$ Fig.5 Result1

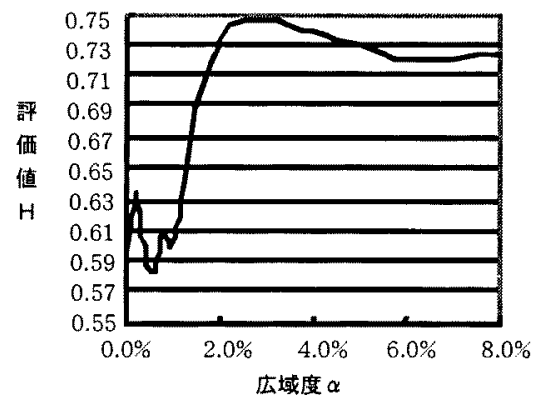

図6 結果 2 : 未知レベル $8, \alpha=1, \beta=0, \gamma=0$ Fig.6 Result2

社会・個人の性質を表す未知レベルや $\alpha, \beta, \gamma$ が分れ ば，図 5 や図 6 に示したグラフを用いることにより，最適 な広域度を算出することは可能ではある.しかし，実際に は,これらの值は不明であり，また，時間とともに変化す る性質を持ち，さらには，評価式Hで定義したようにユー ザが評価することさえ保証されていない.

従って，今回提案した広域的強化学習においては，ユー ザの性質を推測し，その社会の状態にあった最適な推蘑行 動を試行錯誤的に，かつ，特定の評価関数を前提とするこ となく，学習することが必須になる。

次の実験では，強化学習によって社会の变化に対し適応 的に追従できることを実証する。

\section{（3）社会の変化に対する強化学習の有効性の評価}

強化学習機構の有効性を評価するために，「強化学習な し」の広域的強化学習システムと「強化学習あり」の広域的強 化学習システムを対象に比較実験を行った．それぞれのシ ステムの推萀法の選択部分を図7に示す。

本実験ではユーザの評価関数を $\alpha=1, \quad \beta=0, \gamma=0$ と設定した，事前実験により未知レベル $1 \sim 8$ までの結果を 平均したときの最適な広域度が $3 \%$ あるることを得ていた
ので，学習なしでの広域度を3\%にした．

生成番組が 1000 を越えた時点で，社会の性質を末知 レベル8から7へと変化させ, それに追従するかを調べた. 実験結果を図 8 に示す。

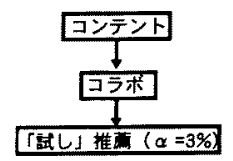

(a) 学習なしの場合

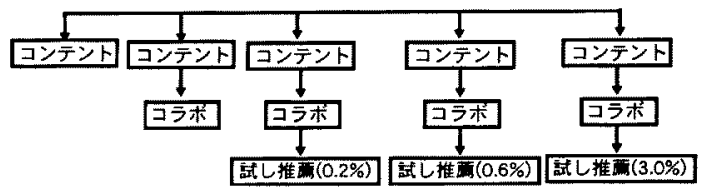

(b)学習ありの場合

図 7 推薦技法の選択の範囲

Fig.7 Variety of Available Recomendatgion Methods

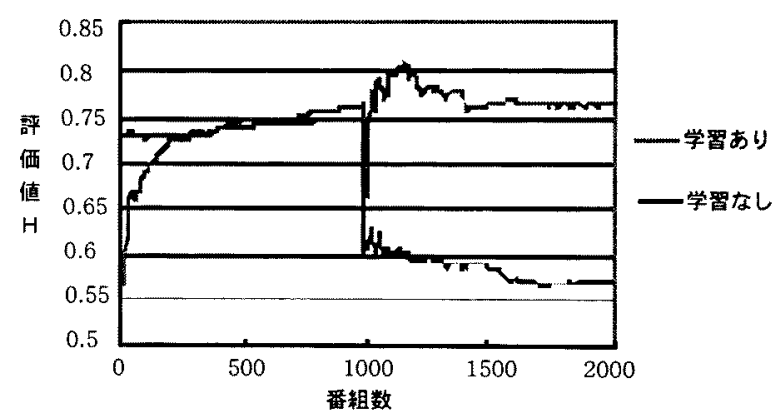

図 8 社会の変化への追従実験

Fig.8 Adaptation to Change of Society

図８において，横軸はシミュレータが生成した番組の累 積数であり，時間の経過を表すものと考えてよい，番組数 が少ない, 即ち, 推葴システムが動作しはじめて間もない 時点においては，「強化学習ありのシステム」は「学習なし」 に比べ推蔍の評価值は悪い。しかし処理する番組が増えて くるにつれ徐々に学習をしていき推薦の評価值は上がって いる.これは学習によって社会・個人にとって好ましい推 薦行動が選ばれるようになるからである。

生成番組数が 1000 を越えた時点で, 社会の性質であ る末知レベルを 7 から 8 に変化している．「学習なし」のシ ステムは推薦行動を修正することができず，評価值が大き く低下する，一方，「学習あり」のシステムも評価値は同様 に落ちるが，短時間で適応し，評価值は復帰している。

以上のように, 今回提案した広域的強化学習システムは 強化学習によって社会の性質やユーザの性質に適応し，最 適な推薦行動を選択可能であることが実証された。 


\section{6. まとめ}

本論文では, 従来の情報推萀手法である, コンテント ベース推薦, コラボレーティプ推萀, および融合システム の $2 つ の$ 本質的問題点を指摘した. 第一の問題点は従来の 推萀システムが人間の自発的な情報摄取行動に依存し過ぎ ている点にある. 第二の問題点はコラボレーティブホライ ズン問題である. 即ち, コラボレーティブ推鷹において, 情報推薦の仮想的なネットワークができ，このネットワー クが閉じたグループを構成してしまう場合, 情報伝播が阻 害されるという問題である.

そこで本論文で提案した広域的強化学習推蔗では, コン テントベース推薦, コラボレーティブ推薦で推薦できない 未知番組, 即ち, ユーザの誰にも見られていない種類の番 組, あるいは, ホライズングループ中のユーザの誰にも見 られていない種類の番組の出現を検知し, 広域度と呼ぶあ る一定の割合で,「試し」に推䳸することにより，情報推䳸 の活性化を図った.

最適な広域度は社会やユーザの性質に大きく依存し，時 間的に変化すると考えられるため, 未知環境での自律的な 学習が可能である強化学習を用いたエージェントアーキテ クチャで寒現した.

シミュレーションにより，「試し」推鹰が確かに情報推鷹 に対して効果があり, また, 最適な広域度は社会やユーザ の性質により大きく変化し, さらに, 強化学習により最適 な推葴行動を学習可能であることを実証した.

これらの結果はコンピュータシミュレーションによる検 証であり，実データを用いた検証を計画している.

(平成12年8月 15 日受付, 同13年1月15日再受付)

（1）長屋 龍人：情報と脳の器〜人間の情報処理限界性と“いいとこ取 り”行動の基礎原理〜。 NHK放送文化調查研究年報 40 ,pp. 1102

（2）白石 信子:「テレビ世代I」人々の情報行動〜「テレビと情報行動」 調查から〜, 放送研究と調查, pp. 2-19(1997)

（3）木根 智也, 田野 俊一: ティジタルTV視聴者の選好推定技法 の分析と提案, 第14回ヒューマン・インターフェイス・シンポジ ウム論文集, pp. 625-628(1998)

（4）本根 智也, 石谷 規彦, 田野 倰一: 広域的強化学習によるティ ジタルTVの番組推荷方の提案と評洒, 第15回ファジィシステム シンポジウム講演論文集, pp. 767-770(1999)

（5）石谷 規彦、木根 智也,田野 俊一：広域的強化学習による情報 推薦における情報伝搬過程の分析, 雨気学会 電子・情報部門大 会 講演論文集, pp. 331-332(1999)

(6) N.Ishitani, T.Kinone, S.Tano : Performance of information recommendation agent based on reinforcement learning in society, Proceedings of the fifth international symposium on artificial life and robotics (AROB 5th 2000), vol.1,pp. 92-95 (2000)

(7) Lashkari, Y. , Metral, M. Maes, P. : Collaborative interface agents, In Proceedings of the National Conference on Artificial Intelligence, MIT Press, Cambridge, Mass, pp. 444449(1994)

(8) Marko Balabanovic and Yoav Shoham: Content-Based, Collaborative Recommendation, Communication of The ACM, Vol.40, No.3, pp. 66-72(1997)

(9) Joachims, T.,Freitag,D and Mitchell, T., : Webwatcher : a tour guide for the World Wide Web, http:// www.cs.cmu.edu/afs/cs/project/theo-6/webagent/ www/techrep.ps.Z(1996)

(10) Alexa(http://www.alexa.com)

(11) Watkins,C.J.C.H. and Dayan,P.: Technical note:Q-Learning, Machine Learning, Vol.8, No.3, pp. 279-292

田 野 俊 一 （非会員）1958年8月3日生. 1981年3月東京工業 大学制御工学科卒業. 1983年3月大学院総合理工 学研究科修士課程修了 同年4月(株) 日立製作所 システム開発研究所. 1990-91年カーネギメロ ン大学客員研究員. 1991-94年国際ファジィ工 学研究所. 1996年4月より, 電気通信大学 大学 院情報システム学研究科助教授. 2000-2001年 マサチュセッツ工科大学客員科学者. 知的ユーザ インタフェースの研究に従事. 情報処理学会, 人工知能学会, 日本 ファジィ学会, 言語処理学会, AAAI, IEEE, ACM各会員.

木 根 智 也 (非会員) 1973年11月16日生. 1997年3月電気通

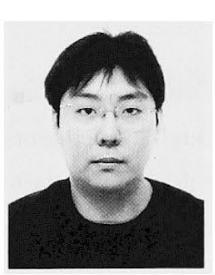
信大学電子工学科卒業. 1999年3月同大学大学院 情報システム学研究科博士前期課程修了. 同年 4 月日本ビクター(株) 勤務.

石 谷 規 彦 (非会員) 1974年12月2日生. 1997年3月電気通信

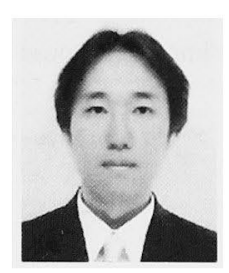
大学機械制御工学科卒業. 2000 年3月同大学大学 院情報システム学研究科博士前期課程修了 同年 4 月(株)ウェザーニューズ勤務. 